\title{
Geology
}

\section{Orbitally forced Azolla blooms and Middle Eocene Arctic hydrology: Clues from palynology}

Judith Barke, Hemmo A. Abels, Francesca Sangiorgi, David R. Greenwood, Arthur R. Sweet, Timme Donders, Gert-Jan Reichart, André F. Lotter and Henk Brinkhuis

Geology 2011;39;427-430

doi: $10.1130 / G 31640.1$

\section{Email alerting services}

\section{Subscribe}

\section{Permission request}

click www.gsapubs.org/cgi/alerts to receive free e-mail alerts when new articles cite this article

click www.gsapubs.org/subscriptions/ to subscribe to Geology

click http://www.geosociety.org/pubs/copyrt.htm\#gsa to contact GSA

Copyright not claimed on content prepared wholly by U.S. government employees within scope of their employment. Individual scientists are hereby granted permission, without fees or further requests to GSA, to use a single figure, a single table, and/or a brief paragraph of text in subsequent works and to make unlimited copies of items in GSA's journals for noncommercial use in classrooms to further education and science. This file may not be posted to any Web site, but authors may post the abstracts only of their articles on their own or their organization's Web site providing the posting includes a reference to the article's full citation. GSA provides this and other forums for the presentation of diverse opinions and positions by scientists worldwide, regardless of their race, citizenship, gender, religion, or political viewpoint. Opinions presented in this publication do not reflect official positions of the Society.

\section{Notes}

(C) 2011 Geological Society of America

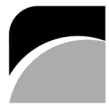

THE

GEOLOGICAL

SOCIETY

OF AMERICA 


\title{
Orbitally forced Azolla blooms and Middle Eocene Arctic hydrology: Clues from palynology
}

\author{
Judith Barke ${ }^{1,2}$, Hemmo A. Abels ${ }^{3}$, Francesca Sangiorgi' ${ }^{1}$, David R. Greenwood ${ }^{4}$, Arthur R. Sweet ${ }^{5}$, Timme Donders ${ }^{6}$, \\ Gert-Jan Reichart ${ }^{7,8}$, André F. Lotter ${ }^{2}$, and Henk Brinkhuis ${ }^{1}$ \\ 'Biomarine Sciences, Institute of Environmental Biology, Department of Biology, Faculty of Sciences, Utrecht University, \\ Budapestlaan 4, 3584 CD Utrecht, Netherlands \\ ${ }^{2}$ Palaeoecology, Institute of Environmental Biology, Department of Biology, Faculty of Sciences, Utrecht University, Budapestlaan 4, \\ 3584 CD Utrecht, Netherlands \\ ${ }^{3}$ Stratigraphy/Paleontology, Department of Earth Sciences, Faculty of Geosciences, Utrecht University, Budapestlaan 4, 3584 CD \\ Utrecht, Netherlands \\ ${ }^{4}$ Department of Biology, Brandon University, 270 18th Street, Brandon, Manitoba R7A 6A9, Canada \\ ${ }^{5}$ Geological Survey of Canada, 330333 Street N.W., Calgary, Alberta T2L 2E7, Canada \\ ${ }^{6}$ TNO, Geological Survey of the Netherlands, PO 80015, 3508 TA, Utrecht, Netherlands \\ ${ }^{7}$ Geochemistry, Department of Earth Sciences, Faculty of Geosciences, Utrecht University, P.O. Box 80.021, 3508 TA Utrecht, \\ Netherlands \\ ${ }^{8}$ Alfred Wegener Institute for Polar and Marine Research, PO Box 1201 61, 27515 Bremerhaven, Germany
}

\section{ABSTRACT}

The high abundances and cyclic distribution of remains of the freshwater fern Azolla in early-Middle Eocene sediments from the Arctic Ocean have previously been related to episodic surface-water freshening, which was speculated to be orbitally modulated. Our integrated palynological and cyclostratigraphical analysis of the recovered Azolla interval in Integrated Ocean Drilling Program (IODP) core 302-M0004A-11X resulted in the recognition of two clear periodicities: a dominant $\sim 1.2 \mathrm{~m}$ cyclicity, which we relate to changes in obliquity ( 40 k.y.), and a weaker $\sim 0.7 \mathrm{~m}$ cyclicity, which we link to precession ( 21 k.y.). Cycles in the abundances of Azolla, cysts of freshwater-tolerant dinoflagellates, and swamp-vegetation pollen show covariability in the obliquity domain. This strong correlation suggests periods of enhanced rainfall and runoff during Azolla blooms, presumably linked to increased local summer temperatures during obliquity maxima. Larix and bisaccate conifer pollen covary at the precession frequency, with peak occurrences corresponding to precession minima, possibly as a result of enhanced continental runoff from a more remote source area and a stronger seasonal contrast. Following the sudden demise of Azolla ca. 48.1 Ma, runoff (cycles) continued to influence the central Arctic at decreased intensity. This and a concomitant decline in swamp-vegetation pollen suggest edaphically drier conditions on land and decreased runoff into the Arctic Ocean, causing salinity changes, which might have been fatal for Azolla. Moreover, a sea-level rise, inferred from overall decreasing total terrestrial palynomorph concentrations, possibly facilitated oceanic connections.

\section{INTRODUCTION}

The modern Arctic Ocean receives a high volume of river inflow; combined with a positive precipitation-evaporation budget of the local basin, this results in surface-water freshening in this largely enclosed basin (Hay et al., 1993; Serreze et al., 2006). The freshwater balance of the Arctic is greatly influenced by orbitally forced (latitudinal) insolation changes, which affect local precipitation and drive the poleward atmospheric heat and moisture transport (Lawrence et al., 2003; Raymo and Nisancioglu, 2003). In an Eocene climate modeling study, Lawrence et al. (2003) showed that during times of maximum seasonal insolation contrast, which could be due to both changes in precession and/or obliquity, precipitation increases at high Northern Hemisphere latitudes, with rises of $\sim 13 \%$ in Siberia, $\sim 23 \%$ in northern Greenland, and $\sim 22 \%$ in northern
North America. Similar changes are simulated when changing high-latitude temperatures (Held and Soden, 2006; Shellito et al., 2009).

During the Eocene Greenhouse conditions, the hydrological cycle was intensified (Huber et al., 2003) and the Arctic atmosphere contained approximately two times more water vapor compared to today (Jahren and Sternberg, 2003). A high precipitation regime prevailed in the western and eastern Arctic, which likely resulted in enhanced freshwater runoff to the Arctic basin (Eldrett et al., 2009; Greenwood et al., 2010), which at the time was nearly entirely enclosed (Jakobsson et al., 2007). High concentrations of megaspores and microspore massulae of the freshwater fern Azolla arctica (Collinson et al., 2009) were recovered from earlyMiddle Eocene marine sediments cored at the Lomonosov Ridge in the central Arctic Ocean (Backman et al., 2006; Brinkhuis et al., 2006). The co-occurrence of different life stages and reproductive parts of Azolla and the absence of land plant detritus show that this floating fern grew in situ on the ocean surface (Brinkhuis et al., 2006; Collinson et al., 2009). Over the recovered 4-m-thick Azolla interval, concentrations of Azolla remains vary between 50,000 and 300,000 specimens/g dry sediment, showing that the intensity of its growth changed episodically (Brinkhuis et al., 2006). Given that Azolla has been restricted to freshwater systems since at least the Paleocene (Collinson, 2002), its presence suggests an episodic substantial freshwater cap on the surface ocean (Brinkhuis et al., 2006). A stratified water column with freshwater on top of more saline deep water is supported by siliceous microfossil data and geochemical proxies (Onodera et al., 2008; Stein et al., 2006; Stickley et al., 2008; Waddell and Moore, 2008).

The fluctuations in the Azolla concentrations are strongly cyclic and have been suggested to be orbitally forced (Brinkhuis et al., 2006). Orbitally induced insolation changes, driving local climate as well as poleward atmospheric heat and moisture transport, likely influenced the amount of precipitation and freshwater discharge into the Arctic Ocean. This suggests that the episodic changes in the freshening of Arctic surface waters and subsequent Azolla pulses could have been astronomically driven. We hypothesize that orbitally driven Azolla changes are accompanied by in-phase changes in the terrestrial elements sensitive to hydrology (vegetation), and marine phytoplankton changes sensitive to salinity. In this study we evaluate the possible underlying forcing mechanisms for these freshwater cycles and the final demise of Azolla ca. 48.1 Ma by applying an integrated palynological and cyclostratigraphical approach. Furthermore, we aim to unravel potentially different impacts of individual orbital frequencies. 


\section{MATERIALS AND METHODS}

The studied material is from core 11X, between 297.31 and $302.63 \mathrm{~m}$ below seafloor (mbsf), from the Lomonosov Ridge Site M0004A in the central Arctic Ocean, cored during Integrated Ocean Drilling Program (IODP) Expedition 302 (or the Arctic coring expedition, ACEX) (Backman et al., 2006; Fig. 1). We examined 54 samples, earlier investigated mainly for Azolla concentrations in the pilot study of Brinkhuis et al. (2006), in detail for palynology. Here we present three aquatic palynomorph records: Azolla and cysts of two freshwater-tolerant dinoflagellate taxa, and five pollen-based records, i.e., total bisaccate pollen, Larix pollen, TCT pollen (Taxodiaceae, Cupressaceae, and/or Taxaceae pollen), Alnus pollen, and pollen of warm-temperate angiosperms. The palynomorph records were analyzed cyclostratigraphically using spectral analysis and bandpass filtering. (For details, see the GSA Data Repository ${ }^{1}$.)

\section{RESULTS}

All samples yield well-preserved, rich palynomorph assemblages showing concentrations as high as 350,000 specimens/g dry sediment. The interval from 298.81 to 302.63 mbsf is dominated by Azolla massulae and is referred to as the Azolla interval (Fig. 2A; see the Data Repository). Furthermore, the samples yield abundant cysts of freshwater-tolerant dinoflagellate taxa, notably Senegalinium spp. (Fig. 2C) and Phthanoperidinium spp. (mainly P. echinatum) (Fig. 2B) (Pross and Brinkhuis, 2005; Sangiorgi et al., 2008; Sluijs and Brinkhuis, 2009). The terrestrial assemblage is rich in angiosperm pollen, mainly deriving from the warmtemperate tree taxa Carya, Fagaceae, Liquidambar, and Ulmus (Fig. 2E),

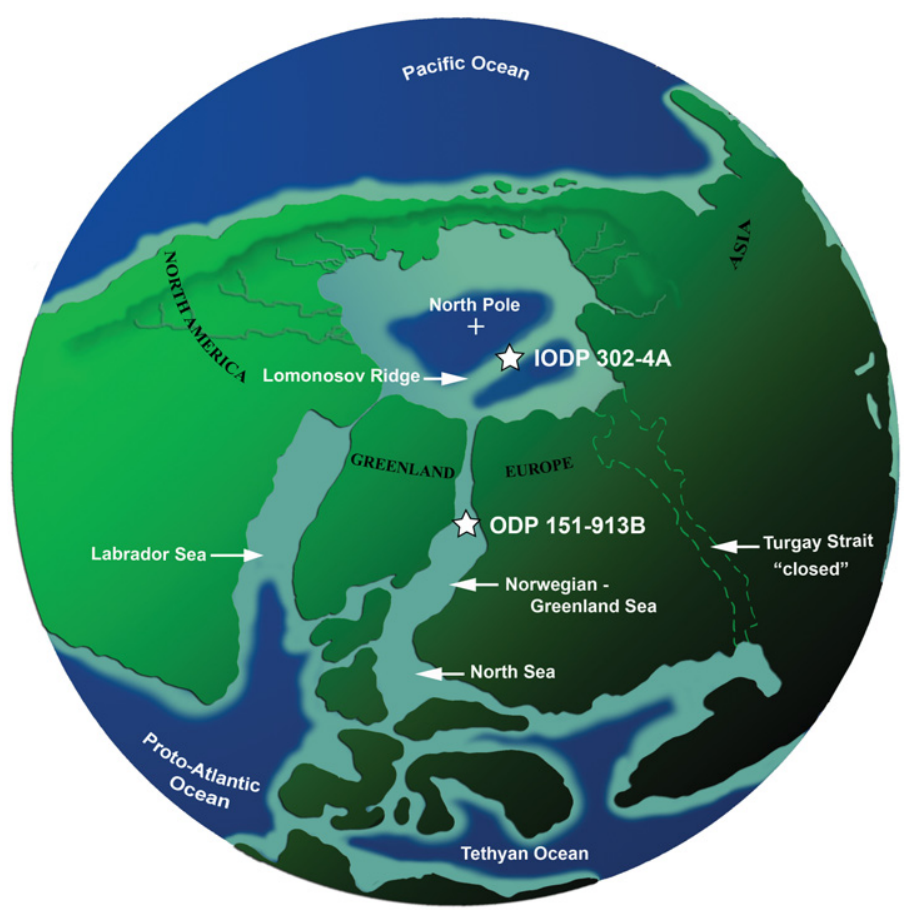

Figure 1. Paleogeographic reconstructions (Middle Eocene; ca. $50 \mathrm{Ma}$ ) showing site locations of Integrated Ocean Drilling Program (IODP) Expedition 302 (or Arctic coring expedition, ACEX) and Ocean Drilling Program (ODP) Expedition 151.

${ }^{1}$ GSA Data Repository item 2011141, supplementary information with extended materials and method section and age assessment, is available online at www.geosociety.org/pubs/ft2011.htm, or on request from editing@geosociety .org or Documents Secretary, GSA, P.O. Box 9140, Boulder, CO 80301, USA. but pollen of cool-temperate taxa is also present, such as Alnus (Fig. 2F). Furthermore, the terrestrial assemblage comprises abundant gymnosperm pollen, including Larix pollen (Fig. 2G), bisaccate pollen from evergreen conifers such as Picea and Pinus (Fig. 2H), and TCT pollen, likely predominated by the swamp-forest genera Metasequoia and/or Glyptostrobus (Fig. 2D). These genera are common in flora macroremains throughout the surrounding Arctic, including the Middle Eocene Axel Heiberg Island assemblages (Greenwood and Basinger, 1994; Greenwood et al., 2010).

All major aquatic and terrestrial palynomorph groups reveal robust cyclic changes in their absolute and relative abundances. Abundances of Azolla and cysts of the freshwater-tolerant dinoflagellate taxa Senegalinium spp. (lower part of percentage record; Fig. 2C) and Phthanoperidinium spp. (Fig. 2B) covary and show a cyclicity with a periodicity of $\sim 1.2 \mathrm{~m}$. Abundances of TCT pollen (Fig. 2D) and pollen abundances of both warm- and cool-temperate angiosperms (Figs. 2E and 2F, respectively) reveal a similar $\sim 1.2 \mathrm{~m}$ cyclic pattern. Peaks in TCT pollen abundances slightly lag Azolla peaks, and the peaks in both angiosperm pollen records are associated with Azolla abundance minima. This opposite phase relation between Azolla and angiosperm pollen abundances is maintained when TCT pollen abundances are excluded from the pollen percentage sum. This implies that the observed phase relation is robust and independent of the TCT pollen abundances. Abundances of Larix and bisaccate pollen (Figs. 2G and 2H, respectively), and Senegalinium spp. (concentration record and upper part of the percentage record; Fig. 2C) reveal cyclicity of $\sim 0.7 \mathrm{~m}$, approximately half the periodicity of Azolla cycles.

At $298.81 \mathrm{mbsf}$, Azolla abundances decrease to just a few specimens per gram, and numbers do not increase again in the upper $150 \mathrm{~cm}$ of the core (Fig. 2A). Simultaneous with the final demise of Azolla, TCT pollen abundances show a sharp decline and remain low in the overlying section (Fig. 2D). The palynological assemblage in the upper $150 \mathrm{~cm}$ of the core (297.31-298.81 mbsf) is dominated by cysts of the freshwater-tolerant dinoflagellate taxon Senegalinium spp. (Fig. 2C). Cyst abundances of the freshwater-tolerant dinoflagellate taxon Phthanoperidinium spp. continue to show an $\sim 1.2 \mathrm{~m}$ cyclic pattern after the demise of Azolla, albeit with a slightly decreased magnitude (Fig. 2B). Total terrestrial palynomorph concentrations gradually decrease throughout the core section (Fig. 2I).

\section{DISCUSSION AND CONCLUSIONS}

Given the average sedimentation rate of $\sim 24.3 \mathrm{~m} / \mathrm{m}$.y. calculated for the Middle Eocene interval (see the Data Repository), we derive a duration of $\sim 49$ k.y. for the dominant $\sim 1.2 \mathrm{~m}$ cyclicity, and $\sim 29 \mathrm{k} . \mathrm{y}$. for the weaker $\sim 0.7 \mathrm{~m}$ cyclicity. Taking the uncertainties in the age model into account (Backman et al., 2008; see the Data Repository), we are confident in relating these cycles to the astronomical-type cycles of obliquity ( 40 k.y. in the early-Middle Eocene; Laskar et al., 2004) and precession ( 21 k.y.), respectively.

Cycles in the abundances of Azolla and cysts of freshwater-tolerant dinoflagellates show a strong correlation in the obliquity domain. This correlation suggests large variations in surface water salinity over time, variations that can be related to changes in local precipitation over the Arctic Ocean and/or river discharge. Synchronous variations in the abundances of swamp-vegetation pollen suggest coeval expansion of swamps on coastal areas surrounding the Arctic Ocean. This implies that regional precipitation changed in-phase with Azolla. Higher obliquity leads to increased summer insolation at high latitudes (Milankovitch, 1941), which in turn is though to enhance total annual precipitation in the Arctic region (Held and Soden, 2006; Lawrence et al., 2003). Sufficient freshening of Arctic Ocean surface waters during the growing season at the same time may have allowed rapid colonization by Azolla of the ocean surface. In addition, a longer growing season during an obliquity maximum could enhance the integrated annual Azolla flux. Conversely, Azolla abundance minima are likely associated with obliquity minima, when less precipitation and reduced runoff may 
have been insufficient to freshen Arctic Ocean surface waters. Still, the sustained low Azolla concentrations show that Azolla growth continued at least part of the year or only in restricted areas. Azolla abundance minima are associated with high abundances of pollen from both cool- and warmtemperate angiosperms. This effectively rules out a large temperature and/ or altitude effect. Rather, this antiphase relationship with Azolla, freshwater-tolerant dinoflagellates, and swamp vegetation suggests that these angiosperms are also primarily driven by humidity. Therefore, peaks in angiosperm pollen are interpreted to indicate edaphically drier conditions on land, which is in line with the supposed overall drier conditions on the continents during obliquity minima.

A surprising second frequency is observed in the abundances of bisaccate and Larix pollen that corresponds with half the duration of the obliquity cycle. This suggests that this frequency either represents the precession cycle or a nonlinear response to obliquity. Since this frequency continues also in the upper part of the record, when the lower frequency signal of obliquity becomes less clear, it most likely reflects a true precession-related climate response.

Precession influences seasonality and thus intensity of summer insolation at the low to middle latitudes (Milankovitch, 1941). Still, a maximum seasonal insolation difference (during precession minima in the Northern Hemisphere) has been shown to result in enhanced total annual precipitation in wide-ranging areas of the Northern Hemisphere, including the high latitudes (Lawrence et al., 2003), and increased continental runoff in North America (Sloan and Huber, 2001). Bisaccate pollen have a good floating and wind-dispersal capacity and are dispersed along large distances relative to other pollen (Traverse, 1988; Hooghiemstra, 1988). The precession signal in these pollen abundances may reflect changes in continental runoff. Enhanced local runoff would, however, also have favored Azolla and Phthanoperidinium abundances, which do not show a precession frequency. The precession signal in these pollen records might therefore reflect a more distant, somewhat lower latitudinal source. Runoff from a more remote source area would have carried comparatively less water relative to local freshwater discharge and may not have freshened Arctic Ocean surface waters sufficiently to sustain the growth of Azolla and Phthanoperidinium. The fact that Senegalinium covaries with bisaccate pollen at the precession frequency, notably in the upper part of the record, suggests that this freshwater-tolerant and heterotrophic dinoflagellate was less sensitive to small changes in salinity and may have responded to an enhanced riverine nutrient input from the more remote source areas.

Furthermore, bisaccate pollen is produced by evergreen conifers, which are expected to be more tolerant of subfreezing rather than milder winter temperatures at high latitudes. Subfreezing temperatures prevent evergreen conifers from staying metabolically active and consuming their resources during the several months of winter darkness, when photosynthesis is inhibited (LePage, 2003; Read and Francis, 1992). Hence, peaks in bisaccate pollen abundances, which go together with peaks in pollen derived from the cold-temperate conifer Larix, may correspond to times of maximum seasonal contrast during precession minima.

It is often observed that obliquity variability within geologic records occurs in intervals of low eccentricity values and thus low precession amplitudes. In our record, the precession signal shows the highest amplitudes in the middle of the studied interval, indicating maximal values of the eccentricity cycle. In addition, the obliquity signal reveals strong amplitude variability in this interval, implying that the obliquity signal is not present in our record due to low eccentricity values. Therefore, we are certain that the obliquity and the precession signals are both derived from different locations and/or climatic or proxy-related mechanisms and do not have the same underlying mechanism.

The final demise of Azolla may have occurred when surface waters no longer became sufficiently fresh during the growing seasons. Although freshwater cycles continued to influence the Arctic Ocean, indicated by the cyclic distribution and dominance of cysts deriving from freshwatertolerant dinoflagellates, a slight increase in salinity may be inferred from a reduction in the concentrations of Phthanoperidinium. Such a slight salinity increase may have crossed the critical threshold for salinity tolerance for Azolla. The concomitant decline of TCT pollen abundances suggests edaphically drier conditions on the surrounding coastal areas. Moreover, the overall decrease in total terrestrial palynomorph concentrations suggests a rise in sea level, which could have facilitated oceanic connections. The associated salinity increase may have been lethal for Azolla, while salt-water intrusion into the coastal areas drastically diminished the saltintolerant swamp forests.

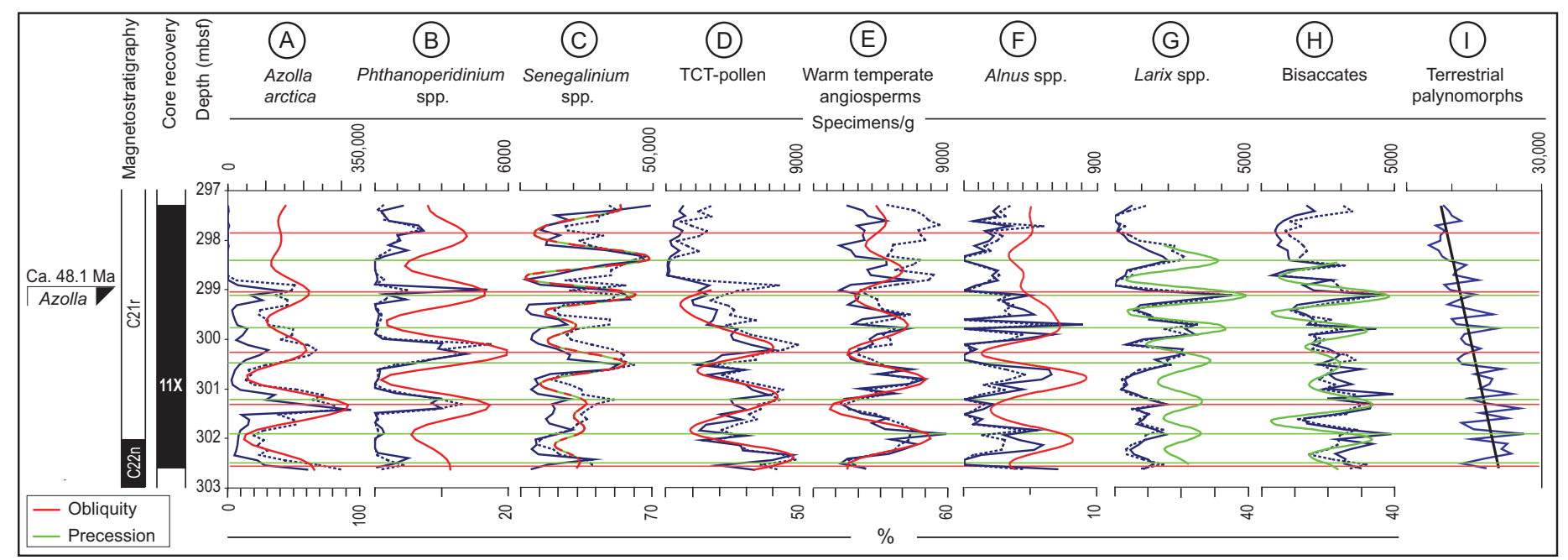

Figure 2. Selection of aquatic and terrestrial palynomorph proxy data from Integrated Ocean Drilling Program (IODP) core 302-M0004A-11X and interpreted orbital cyclicity. Concentration data (specimens/g) are given in solid blue lines with scale bars on upper $X$ axes. Percentages are given in dashed blue lines with scale bars on lower $X$ axes. Percentages are calculated relative to following. A: Total aquatic assemblage. B, C: Total dinocyst assemblage. D-G: Total of all angiosperm and gymnosperm pollen, excluding bisaccate pollen. H: Total pollen assemblage (for details, see the Data Repository [see footnote 1]). TCT pollen-Taxodiaceae, Cupressaceae, and/or Taxaceae pollen. Gaussian bandpass filter is shown in red (obliquity) and green (precession). Y axis shows depth in meters below seafloor (mbsf), core recovery, and magnetostratigraphy. 


\section{ACKNOWLEDGMENTS}

We thank L. Bik, N. Welters, and J. van Tongeren for their great support, and C. Greenwood, J.H.A. van Konijnenburg-van Cittert, and H. Visscher for pollen analytical assistance. We also thank J. van der Burgh and M.E. Collinson for discussions on the ecology of Azolla, and F.J. Hilgen and L.J. Lourens for discussions on spectral analysis. Jerry Dickens and two anonymous reviewers are also acknowledged. This research used samples and data provided by the Integrated Ocean Drilling Program. This is publication DW-2009-5006 of the Darwin Center for Biogeosciences, which partially funded this project. We thank Statoil for their financial support. Greenwood's research is supported by the Natural Sciences and Engineering Research Council of Canada.

\section{REFERENCES CITED}

Backman, J., Moran, K., McInroy, D.B., and Mayer, L.A., and the Expedition 302 Scientists, 2006, Proceedings of the Integrated Ocean Drilling Program Volume 302: Edinburgh, Integrated Ocean Drilling Program Management International, Inc., doi: 10.2204/iodp.proc.302.2006.

Backman, J., and 13 others, 2008, Age model and core-seismic integration for the Cenozoic Arctic Coring Expedition sediments from the Lomonosov Ridge: Paleoceanography, v. 23, PA1S03, doi: 10.1029/2007PA001476.

Brinkhuis, H., 21 others, and the Expedition 302 Scientists, 2006, Episodic fresh surface waters in the Eocene Arctic Ocean: Nature, v. 441, p. 606-609, doi: 10.1038 /nature 04692 .

Collinson, M.E., 2002, The ecology of Cainozoic ferns: Review of Palaeobotany and Palynology, v. 119, p. 51-68, doi: 10.1016/S0034-6667(01)00129-4.

Collinson, M.E., Barke, J., van der Burgh, J., and van Konijnenburg-van Cittert, J.H.A., 2009, A new species of the freshwater fern Azolla (Azollaceae) from the Eocene Arctic Ocean: Review of Palaeobotany and Palynology, v. 155, p. 1-14, doi: 10.1016/j.revpalbo.2008.12.014.

Eldrett, J.S., Greenwood, D.R., Harding, I.C., and Huber, M., 2009, Increased seasonality through the Eocene to Oligocene transition in northern high latitudes: Nature, v. 459, p. 969-973, doi: 10.1038/nature08069.

Greenwood, D.R., and Basinger, J.F., 1994, The paleoecology of high-latitude Eocene swamp forests from Axel Heiberg Island, Canadian High Arctic: Review of Palaeobotany and Palynology, v. 81, p. 83-97, doi: 10.1016/0034 -6667(94)90128-7.

Greenwood, D.R., Basinger, J.F., and Smith, R.Y., 2010, How wet was the Arctic Eocene rainforest? Estimates of precipitation from Paleogene Arctic macrofloras: Geology, v. 38, p. 15-18, doi: 10.1130/G30218.1.

Hay, W.W., Eicher, D.L., and Diner, R., 1993, Physical oceanography and water masses in the Cretaceous Western Interior Seaway, in Caldwell, W.G.E., and Kauffman, E.G., eds., Evolution of the Western Interior Basin: Geological Association of Canada Special Publication 39, p. 297-318.

Held, I.M., and Soden, B.J., 2006, Robust responses of the hydrological cycle to global warming: Journal of Climate, v. 19, p. 5686-5699, doi: 10.1175/ JCLI3990.1.

Hooghiemstra, H., 1988, Palynological records from Northwest African marine sediments: A general outline of the interpretation of the pollen signal: Royal Society of London Philosophical Transactions, ser. B, v. 318, p. 431-449.

Huber, M., Sloan, L.C., and Shellito, C.J., 2003, Early Paleogene oceans and climate: A fully coupled modeling approach using the NCAR CCSM, in Wing, S.L., et al., eds., Causes and consequences of globally warm climates in the early Paleogene: Geological Society of America Special Paper 369, p. 25-47, doi: 10.1130/0-8137-2369-8.25.

Jahren, A.H., and Sternberg, L.S.L., 2003, Humidity estimate for the middle Eocene Arctic rain forest: Geology, v. 31, p. 463-466, doi: 10.1130/ 0091-7613(2003)031<0463:HEFTME >2.0.CO;2.

Jakobsson, M., Backman, J., Rudels, B., Nycander, J., Frank, M., Mayer, L., Jokat, W., Sangiorgi, F., O'Regan, M., Brinkhuis, H., King, J., and Moran, K., 2007, The early Miocene onset of a ventilated circulation regime in the Arctic Ocean: Nature, v. 447, p. 986-990, doi: 10.1038/nature05924.

Laskar, J., Robutel, P., Joutel, F., Gastineau, M., Correia, A.C.M., and Levrard, B., 2004, A long-term numerical solution for the insolation quantities of the
Earth: Astronomy \& Astrophysics, v. 428, p. 261-285, doi: 10.1051/0004 $-6361: 20041335$.

Lawrence, K.T., Sloan, L.C., and Sewall, J.O., 2003, Terrestrial climatic response to precessional orbital forcing in the Eocene, in Wing, S.L., et al., eds., Causes and consequences of globally warm climates in the early Paleogene: Geological Society of America Special Paper 369, p. 65-77, doi: 10.1130/08137-2369-8.65.

LePage, B.A., 2003, A new species of Thuja (Cupressaceae) from the Late Cretaceous of Alaska: Implications of being evergreen in a polar environment: American Journal of Botany, v. 90, p. 167-174, doi: 10.3732/ajb.90.2.167.

Milankovitch, M., 1941, Kanon der Erdbestrahlung und seine Anwendung auf das Eiszeitenproblem: Royal Serbian Academy Special Publication 133, $633 \mathrm{p}$.

Onodera, J., Takahashi, K., and Jordan, R.W., 2008, Eocene silicoflagellate and ebridian paleoceanography in the central Arctic Ocean: Paleoceanography, v. 23, PA1S15, doi: 10.1029/2007PA001474.

Pross, J., and Brinkhuis, H., 2005, Organic-walled dinoflagellate cysts as paleoenvironmental indicators in the Paleogene; a synopsis of concepts: Paläontologische Zeitschrift, v. 79, p. 53-59, doi: 10.1007/BF03021753.

Raymo, M.E., and Nisancioglu, K., 2003, The 41 kyr world: Milankovitch's other unsolved mystery: Paleoceanography, v. 18, 1011, doi: 10.1029/ 2002PA000791.

Read, J., and Francis, J.E., 1992, Responses of some Southern Hemisphere tree species to a prolonged dark period and their implications for high-latitude Cretaceous and Tertiary floras: Palaeogeography, Palaeoclimatology, Palaeoecology, v. 99, p. 271-290, doi: 10.1016/0031-0182(92)90019-2.

Sangiorgi, F., van Soelen, E.E., Spofforth, D.J.A., Pälike, H., Stickley, C.E., St. John, K., Koç, N., Schouten, S., Sinninghe Damsté, J.S., and Brinkhuis, H., 2008, Cyclicity in the middle Eocene central Arctic Ocean sediment record: Orbital forcing and environmental response: Paleoceanography, v. 23, PA1S08, doi: 10.1029/2007PA001487.

Serreze, M.C., Barrett, A.P., Slater, A.G., Woodgate, R.A., Aagaard, K., Lammers, R.B., Steele, M., Moritz, R., Meredith, M., and Lee, C.M., 2006, The large-scale freshwater cycle of the Arctic: Journal of Geophysical Research, v. 111, C11010, doi: 10.1029/2005JC003424.

Shellito, C.J., Lamarque, J.F., and Sloan, L.C., 2009, Early Eocene Arctic climate sensitivity to $\mathrm{pCO}_{2}$ and basin geography: Geophysical Research Letters, v. 36, L09707, doi: 10.1029/2009GL037248.

Sloan, L.C., and Huber, M., 2001, Eocene oceanic responses to orbital forcing on precessional time scales: Paleoceanography, v. 16, p. 101-111, doi: 10.1029/1999PA000491.

Sluijs, A., and Brinkhuis, H., 2009, A dynamic climate and ecosystem state during the Paleocene-Eocene Thermal Maximum-Inferences from dinoflagellate cyst assemblages at the New Jersey Shelf: Biogeosciences, v. 6, p. 1755-1781, doi: 10.5194/bg-6-1755-2009.

Stein, R., Boucsein, B., and Meyer, H., 2006, Anoxia and high primary production in the Paleogene central Arctic Ocean: First detailed records from Lomonosov Ridge: Geophysical Research Letters, v. 33, L18606, doi: 10.1029/2006GL026776.

Stickley, C.E., Koç, N., Brumsack, H.J., Jordan, R.W., and Suto, I., 2008, A siliceous microfossil view of middle Eocene Arctic paleoenvironments: A window of biosilica production and preservation: Paleoceanography, v. 23, PA1S14, doi: 10.1029/2007PA001485.

Traverse, A., 1988, Paleopalynology: Boston, Unwin Hyman, 600 p.

Waddell, L.M., and Moore, T.C., 2008, Salinity of the Eocene Arctic Ocean from oxygen isotope analysis of fish bone carbonate: Paleoceanography, v. 23, PA1S12, doi: 10.1029/2007PA001451.

Manuscript received 3 August 2010

Revised manuscript received 23 November 2010

Manuscript accepted 5 December 2010

Printed in USA 